\title{
Rural Development as Working With People: The Particular Case in Mountains Area of Avila, Spain
}

\author{
(Miriam López, Raquel Pastor, Victor Luís de Nicolás)
}

\begin{abstract}
Despite efforts from all areas and levels of European, national, regional and local policies, the lack of entrepreneurship initiatives remains one of the main problems in many rural areas. Given the lack of effective public initiatives, today there is a need for new approaches based on civil society playing a greater role in promoting rural development and entrepreneurship in endogenous development projects. In this context, the main objective of the research is to study best strategies and tools to planning a new model which aims to generate entrepreneurship and innovation in rural areas by engaging civil society. This new model is based on the 'Working With People' meta--model by adapting its elements to the special conditions of the context in which it is applied. This adaptation results in an entrepreneurship program for rural sustainability that is being conducted in the Sierra de Avila region, Spain, and supported by a private non-profit organization called the 'Tatiana Perez de Guzmán el Bueno' Foundation. After continuous work with the locals, the designed tools have been able to generate the first entrepreneurial projects since the implementation.
\end{abstract}

Keywords-rural entrepreneurship; rural development; sustainability, Working With People; capacity building; publicprivate partnership

\section{Introduction}

Entrepreneurship is an old but continually emerging field that attracts the attention of academics, policymakers and practitioners in various fields of economics, finance, management and sociology (1). In recent decades it has been studied as a catalyst for development and a key factor for achieving economic growth, job creation and increased productivity $(2,3)$. With regards to the rural context, the limited research that has been done (4) mainly relates to concepts such as organizations, policies and institutional and governance frameworks (5). Rural entrepreneurship has particular attributes (6-8) -large distances from points of sale, specialized market, predominance of primary sector activities, dense "networks" of mutual control, etc. that influence entrepreneurial activity in several ways (9). Hence the importance of empirical studies that shed light on strategies to promote entrepreneurship.

In this context, the main objective of the research is to study best strategies and tools to planning a new model that aims to generate entrepreneurship and innovation in rural areas engaging the civil society and thereby contributing to empirical research on the promotion of entrepreneurship. This model is based on the 'Working With People' (WWP) metamodel (10-12) by adapting its elements to the special conditions of the context in which it is applied. This adaptation results in an entrepreneurship program for rural sustainability that is being carried out in 17 municipalities in the Sierra de Avila region, Spain, in an area with deep aging and depopulation problems. The funding for the Project comes from a private non-profit organization called the 'Tatiana Perez de Guzmán el Bueno' Foundation. After continuous work with the locals, it has been possible to incorporate several tools into the model in order to promote entrepreneurship. The tools designed for configuring this entrepreneurial model consist of a capacity building and advisory plan, a financing system and a public-private partnership. These tools have created synergies between agents and entrepreneurial ideas from the rural population that have resulted in the first projects since the implementation.

\section{A. Background}

The "Young Entrepreneurs for the Sustainability of Rural Territories Program" or JESTeR program is the result of an agreement between a Private Foundation, Tatiana Perez de Guzman el Bueno Foundation (TPGB Foundation) and the Technical University of Madrid (UPM), through the Gesplan research group. The TPGB Foundation is a non-profit foundation that manages the legacy of its founder, and has mainly social goals in youth training, scientific research and environmental fields (13). These aims have led the Foundation to collaborate with different Spanish universities with the objective of promoting research projects in different scientific fields. The rural environment is one of the areas where the Foundation aims to promote development initiatives and training for young people, especially women. The Foundation's interest in this area led them to look for relevant experts and researchers within the University with experience in sustainable rural development, to collaborate with the Foundation in achieving its objectives. The agreement was consolidated as a University-Enterprise Chair, between the TPGB Foundation and the UPM. These structures, UniversityEnterprise Chairs are a means to establish a strategic and lasting partnership between the University and a company or entity to carry out training, research and knowledge development or transfer in an area of common interest. Within this framework of collaboration, it has been possible to generate an entrepreneurship model, in which the participation of local people has played a key role.

M. López, R. Pastor, V.L. de Nicolás

line 1 Technical University of Madrid line 2: Spain

\section{Territorial context}

The geographic scope consists of 17 municipalities in the Sierra de Avila región (Figure 1), located in the largest autonomous community of Spain, Castilla y Leon. This is one 
Proc. of the Fourth International Conference on Advances in Social Science, Management and Human Behaviour - SMHB 2016. Copyright ( ) Institute of Research Engineers and Doctors. All rights reserved.

ISBN: 978-1-63248-116-0 doi: 10.15224/ 978-1-63248-116-0-59

of the most sparsely populated areas of the Spanish territory, with 1,632 inhabitants in $379 \mathrm{~km} 2$, representing a population density of 4.77 inhabitants per $\mathrm{km} 2$. The low population density stands out, compared to rural Spain which has an average of 93.43 inhabitants / km2 (14) at a national level 19.79 inhabitants / km2 (15), and at European level 118.67 inhabitants / km2 (16). Despite the small population and an aging population pyramid, the area has a cohesive geographic unit with numerous natural, cultural and environmental resources. The predominant productive activity is dry farming, with $40.5 \%$ of the area occupied by meadows and pastures (mainly barley and wheat) and livestock production is focused on bovine meat and milk (17).

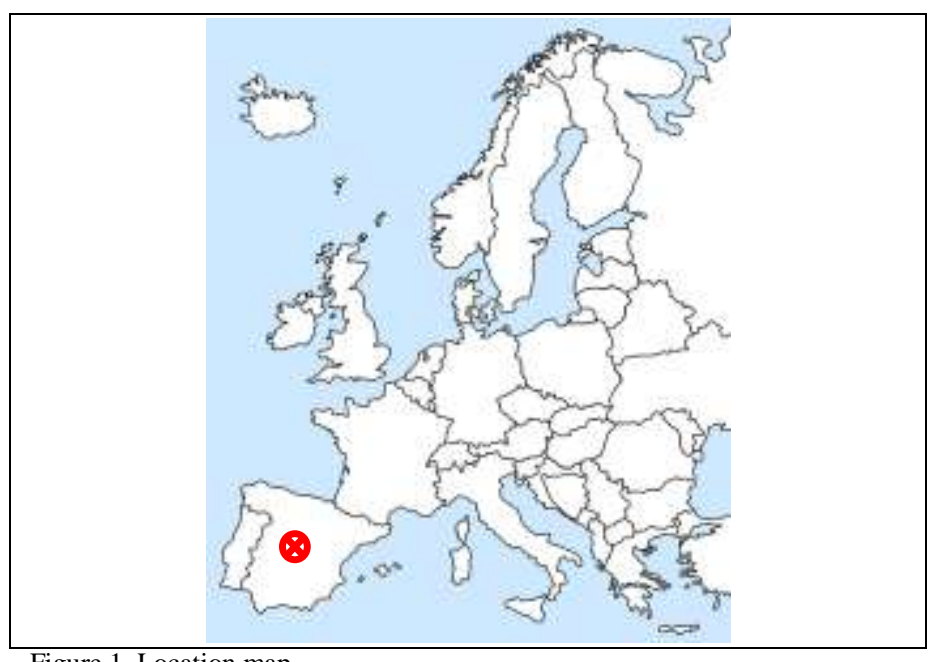

Figure 1. Location map

For more than 15 years, in the rural areas of Sierra de Avila, various development programs based on the European LEADER approach have been carried out through national PRODER programs. However, the program's territory is one of the areas with less activity compared to other more populated and dynamic rural surroundings.

\section{Methodology}

The research methodology is based on the "Working With People" (WWP) model (10-12). It is configured as a metamodel whose application results in a professional practice that connects knowledge and actions, to develop, implement and evaluate development projects in rural areas. The guiding principles of this model are: respect and primacy for the people, to guarantee social well-being and sustainable development, a bottom-up and multidisciplinary approach and an endogenous and integrated approach. Given these principles, the model incorporates three pillars (Figure 2) or basic components: social-ethical, technical-entrepreneurial and political-contextual. This involves the inclusion of a planning entrepreneur role. This planning entrepreneur is the intermediary between the public and private powers, who also acts as a resource manager capable of negotiating in turbulent environments with various actors in order to connect public efforts with social demands (18).

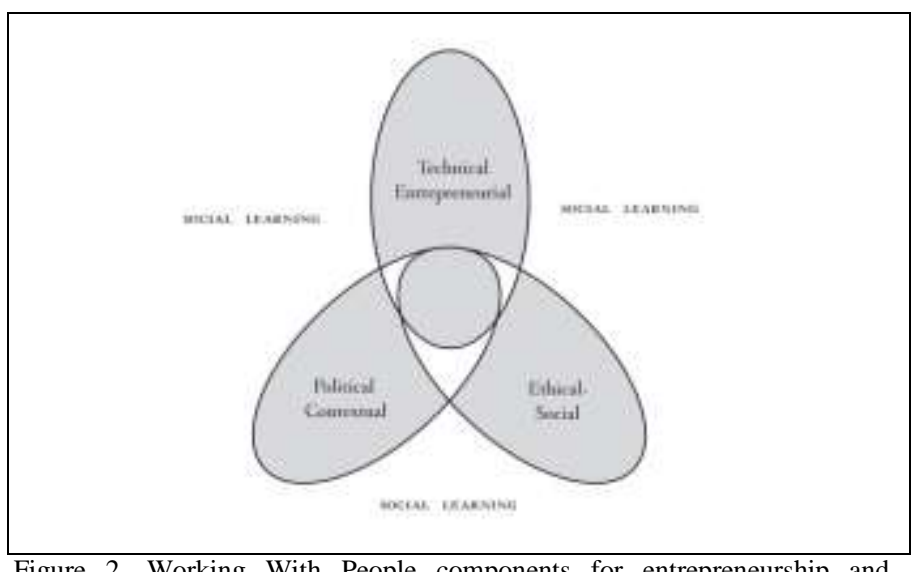

Figure 2. Working With People components for entrepreneurship and innovation

The model highlights the importance of the local participation processes, skills acquisition and agents mobilization to ensure that entrepreneurs have the appropriate skills (behavior, negotiation, commitment and leadership) to direct their projects and achieve public-private interaction. (19). The WWP model seeks to implement projects, and not activities, taking into account the traditions and values, respecting people and caring for the environment. These values should be included in the projects to achieve long-term success. Innovation in the search for new solutions, the bottom-up approach and the incorporation of the territorial approach enables the articulation and design of an effective strategy to promote development aimed at solving the real problems faced by the population (20).

The political-contextual component provides the entrepreneurship model with the key elements for recognizing and understanding the context in which projects are inserted, enabling the establishment of relationships with political entities and the public administration. On the other hand, the technical-entrepreneurial component is mainly related to the private-sector, and integrates the elements that allow the model to develop a mobilizing role of human, economic, public and private resources. Finally, the ethical-social component is identified with the social subsystem, covering the context of attitudes and values of people involved in the project. Ethics and values are integrated in the project to overcome potential moral conflicts related to the parties involved with it (21). Reciprocity, trust and cooperation are the strategies needed to ensure the success of the Program across the different social levels. In order to achieve a broad understanding of the local population, it is necessary to be in touch with the different associations, communities, local action groups (LAG), and other dynamic agents in the territory.

The implementation of the Working With People metamodel has resulted in different applications that have adapted the components to different contexts and regions, with their specific conditions. Among the predecessors to our case study the following application cases are highlighted: in the North Highland of Madrid's community (Spain) related to Public-Private Partnerships focus on promoting entrepreneurship (22); in Aymara's communities of Puno (Peru). related to entrepreneurship focus on craftswomen (12); 
in the Region of Murcia (Spain), related to organic agricultural and biodynamic crops (23); in Region of La Macarena (Colombia), related to strategies for the eradication of illicit crops (24); in the Region of Cuenca (Spain), related to a hydraulic engineering project (25) and in Rural Regions of Rumania, related to project management competencies affecting regional development (26).

\section{A. JESTeR Program: design, phases and activities}

The JESTeR program is configured as a new application of the WWP model in a specific context and conditions. The objective pursued with the implementation of this program is to promote entrepreneurship and innovation projects with a sustainable and environmentally friendly approach in several rural municipalities which are characterized by depopulation and aging. It is aimed at the local population, giving special priority to women and young people. The elements that characterize the program are the result of participatory collaboration between different stakeholders involved in the program. The decision-making throughout each phase or activity -summarized in Table I- has been the result of a dynamic, flexible and fluid process agreed multilaterally by the various parties involved.

TABLE I. LIST OF PHASES AND ACTIVITIES CARRIED OUT SO FAR IN THE JESTER PROGRAMME

\begin{tabular}{|c|c|}
\hline Phases & Activities \\
\hline Launch & $\begin{array}{l}\text { Documentation collection, formulation, } \\
\text { bidirectional information, tools analysis }\end{array}$ \\
\hline Participatory diagnosis & $\begin{array}{l}\text { Interviews (institutional agents and } \\
\text { municipalities mayors), WWP workshops } \\
\text { (entrepreneurs and businessmen), surveys } \\
\text { (entrepreneurs), completion of the diagnostic } \\
\text { report }\end{array}$ \\
\hline Strategy design & $\begin{array}{l}\text { Roundtables, information analysis, tools and } \\
\text { procedure design (capacity building plan, } \\
\text { financing and advisory system and public- } \\
\text { private partnership), completion of the design } \\
\text { strategy report }\end{array}$ \\
\hline Implementation & calls for projects ( 2 rounds), courses, funding \\
\hline Monitoring and control & $\begin{array}{l}\text { project monitoring, review procedures, } \\
\text { adapting tools to new agents }\end{array}$ \\
\hline
\end{tabular}

Currently, the JESTeR program is in its second call for projects, while in parallel, the monitoring and control of the projects launched in the first call is being carried out.

\section{Results}

The research results presented are divided into two key elements in order to show how the JESTeR program has been designed and fitted in this context, and how It is being implemented so far throughout two calls of projects. On one hand, the designed tools to promote rural entrepreneurship and innovation are presented as the result of the participatory process. On the other hand, the first results of the management model of the JESTeR Strategy are presented in order to show how this ongoing program has led to the initial results that have materialized in the first entrepreneurial and innovative projects.

\section{A. Entrepreneurship and Innovation JESTeR-Strategy: Tools}

The entrepreneurship and innovation tools that were designed, and which are based on the WWP participatory processes, are the key to the joint strategy on which the model of entrepreneurship and innovation of the JESTeR program relies on.

A.1. Capacity Building Plan and Personalized Counselling: Project-Based Learning approach:

The JESTeR program's Capacity Building Plan aims to support entrepreneurs with the implementation of their own innovation and entrepreneurship projects based on ProjectBased Learning, to improve or enhance their skills related to entrepreneurship, project management and other specific areas. The Plan was structured in three major thematic areas, but as in the rest of the designed tools, it is open to future updates based on the needs and opportunities that may arise. The three thematic areas are: 1- Project Management for entrepreneurs. Courses included: "The Entrepreneur Project Manager: competence baseline" and "Basic accounting and business plan design"; 2- Information and communication technologies (ICTs). Courses included: "Adoption of new information and communication technologies"; 3- Specific courses: Any other course selected by entrepreneurs and related to their own projects. This Capacity building plan involved a Project-Based Learning (PBL) approach that has enabled methodological aspects to be adapted in teaching for real projects (Business plan and the Entrepreneur Project), as the most suitable means of achieving effective competencebased education that integrates knowledge, skills and values $(27,28)$.

Along with the capacity building plan, a Personalized Assessment System is implemented in a coordinated manner and it is aimed at entrepreneurs who are developing their skills through their own businesses. This system is supported by the experts and professionals from the capacity building plan, either as teachers or as tutors for the individual monitoring of projects and activities; In addition, it is completed with the participation of other members of the partnership to support entrepreneurs in the implementation and execution of their projects.

\section{A.2. Funding system for the entrepreneur projects:}

The model's second tool consists of a funding system for entrepreneurial projects and the associated training process. It is a co-financing system for the implementation of small innovative projects promoted by local entrepreneurs or by people or groups of people from outside the territory interested in undertaking new business opportunities in this geographical area. The system is aimed at facilitating greater adaptability and increasing the capacity of entrepreneurs for addressing projects. It is a co-financing system between the entrepreneur/s and the TPGB Foundation. Since their inception, the projects approved under the program benefit from non-refundable grants for launching the project and receive a loan which is provided under the terms agreed in advance between all the parties for its execution during the 
Proc. of the Fourth International Conference on Advances in Social Science, Management and Human Behaviour - SMHB 2016. Copyright ( ) Institute of Research Engineers and Doctors. All rights reserved.

ISBN: 978-1-63248-116-0 doi: 10.15224/ 978-1-63248-116-0-59

first or early years. This system seeks to combine financial support for entrepreneurs -especially in the early stages of project design and project implementation-, the effort and commitment of entrepreneurs -as co-financiers of their proposals-, and a monitoring system based mainly on relationships of mutual trust. On the other hand, funding for the Capacity Building Plan is also part of the program's funding system. In this case, all courses received financing of between $50 \%$ and $80 \%$ of the total.

\section{A.3. Public-Private Partnership for JESTeR program:}

For the creation of this partnership, the possible constituent groups were studied so that most organizations integrated in the territory would be represented. Also, members of the partnership have been identified based on the positive effects their actions have on creating strategic alliances between the territory's different actors and the generation of synergies in the territory that go beyond the very objectives of the JESTeR Program. Thus, four different groups were integrated into the PPP: a group of six mayors from the municipalities within the territory -the members of this group change annually through a voting system-; a group of three dynamic agents of the territory, composed of representatives from associations and rural development agents related to the territory; a group of external advisors, made up of four members representing food companies, entrepreneurs and managers of local action groups from other territories with extensive experience in the entrepreneurship and innovation fields; and a group formed of four members from the Gesplan technical team. The latter group, in its role as planner, assumed the role of intermediary between the partnership's different groups, population, entrepreneurs, businessmen and the TPGB Foundation as the sponsor of the program. This partnership has had as its main functions the sharing and evaluation of proposals submitted by entrepreneurs for inclusion within the JESTeR program and the drafting of reports for improvements in project proposals submitted with the aim of ensuring their feasibility. The assessments are carried out under a multi-criteria approach taking into account socio-economic, technical and environmental aspects, with particular emphasis on those with the highest degree of innovation, synergy creation, or those promoted by women and young entrepreneurs aged between 18 and 40 years old.

\section{B. Entrepreneurship JESTeR-Strategy: Management Model Implementation}

The entrepreneur project management model integrates different processes designed and agreed between the local population and the actors in the public and private sector. It is a model that follows the project cycle, incorporating expert knowledge and experienced knowledge between the planning team and the affected population in each of the different phases (29). It is a flexible management model, which allows adjustments to be made as new information is obtained and which also leads to the implementation of new projects in the territory. The management model for the implementation of this strategy is shown schematically in Figure 3:

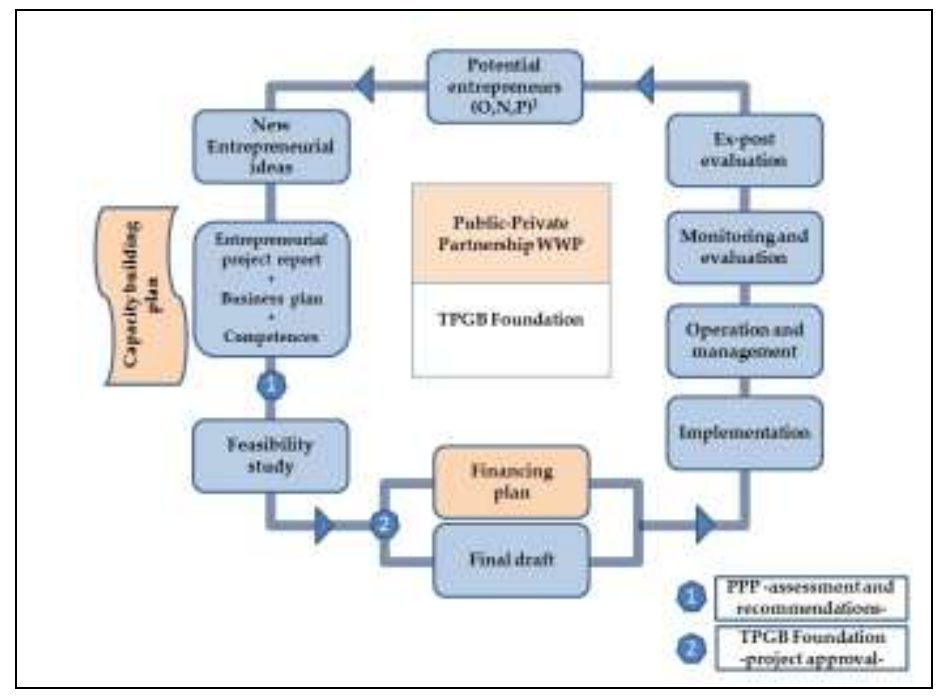

Figure 3. Entrepreneur project management cycle with the WWP approach (Source: Cazorla et al., 2010).

So far, according to this management model, the six projects that have been launched are distributed within the thematic areas of the strategy as shown in Table II:

TABLE II. PROJECTS AND THEMATIC AREAS

Thematic axis 1: Livestock farming and Agri-food

Poultry project: Egg production (Free-ranging hens) ${ }^{\mathrm{a}}$

Beekeeping project 1: Honey production (mixed flower and oak) ${ }^{\mathrm{a}}$

Beekeeping project 2: Honey production (mixed flower and oak) ${ }^{\mathrm{b}}$

Cattle project: Beef cattle feedlot ${ }^{\mathrm{b}}$

Thematic axis 2: Tourism, cultural heritage and craft

none

Thematic axis 3: non agri-food and livestock SMEs

Mechanical project: Innovation in agricultural plowing ${ }^{a}$

ICT services Project: Online sale (Parapharmacy, dietetics and cosmetic products) $)^{\mathrm{a}}$

a. First call for projects b. Second call for projects

Regarding the impact and sustainability of these projects, it is important to highlight that the program is currently at an early stage. It is not yet possible to determine the impact that these projects will have on the territory or their sustainability over time. However, it has been found through the workshops during the second round of projects, that the first ventures have had a 'pull effect' on the local population.

\section{v. Conclusions}

The application of the WWP meta-model to this specific context has required the participation of local actors directly involved in endogenous development. The three components of the meta-model (social-ethical, technical-entrepreneurial and political-contextual) have allowed structure and materialize the design of the program tools through the identification of people, resources, needs and potencial.

The results of the implementation of the JESTeR program based on the WWP model principles have generated a 
Proc. of the Fourth International Conference on Advances in Social Science, Management and Human Behaviour - SMHB 2016. Copyright ( ) Institute of Research Engineers and Doctors. All rights reserved.

ISBN: 978-1-63248-116-0 doi: 10.15224/ 978-1-63248-116-0-59

typology of project ideas that are fostering entrepreneurship and dynamism in one of the most sparsely populated rural areas of Spain. The JESTeR program is therefore an experimental and innovative way of addressing rural development. Although it contains elements of the LEADER approach -territorial approach, innovation, cooperation, building partnerships and participative structures- the model incorporates a more decentralized and independent management of public aid, by being managed and designed directly by civil society and representatives from the business world.

The processes of capacity building, from Projects Based Learning, are shown to be a key tool in the cooperation, networking and skills development model for the entrepreneurs' project management skills.

The creation of a partnership, as a local territorial structure, has been developed in parallel with participatory assessments, training and awareness activities of the entrepreneurs from the elected rural municipalities. In the JESTeR program, the creation of a PPP is particularly innovative, as territorial governmental structures supported by an organization and technical team to advise and assist on the implementation of rural entrepreneurship and innovation projects. The novel structure of this partnership, which includes business agents and external consultants, is shown to be an element with great potential in the territory for joint venture projects, rural development and local capacity building.

The funding system adopted, as a driving tool of the project, also shows a novel approach, as nothing similar exists in the Spanish rural territory. The co-financing of projects between entrepreneurs and the TPGB Foundation, implies a collaboration agreement and a commitment in which the values of trust and professional ethics are exalted, including flexible terms adjusted to the real needs of entrepreneurs.

Finally, it is important to note that international trends on entrepreneurship and sustainability based on enhanced responsibility, commitment and initiatives of the civil society, are in line with the principles of the adopted model.

\section{References}

[1] P. J. Kaufmann and R.P. Dant, "Franchising and the domain of entrepreneurship research," J Bus Venturing 1999, 14(1), 5-16.

[2] S. C. Parker, The economics of entrepreneurship. Cambridge University Press. 2009.

[3] C. M. Van Praag and P. H. Versloot, "What is the value of entrepreneurship? A review of recent research," Small Bus. Econ 2007, 29(4): 351-382.

[4] N. Meccheri and G. Pelloni, "Rural entrepreneurs and institutional assistance: an empirical study from mountainous Italy," Entrep Region Dev 2006, 18 (5), 371-392.

[5] M. L. Pato and A. Teixeira, "Twenty years of rural entrepreneurship: a bibliometric survey," Sociol Ruralis 2014, 56 (1), 3-28.

[6] D. North and D. Smallbone, "Innovative activity in SMEs and rural economic development: Some evidence from England," Eur Plan Stud 2000, 8(1), 87-106.

[7] S. Stathopoulou, D. Psaltopoulos and D. Skuras, "Rural entrepreneurship in Europe: a research framework and agenda." Ijebr 2004, 10(6), 404425 .
[8] D. Smallbone, Rural entrepreneurship. In Strengthening entrepreneurship and economic development in East Germany: Lessons from local approaches, ed. J. Hofer, 161-89. Paris: OECD. 2009.

[9] D. Baumgartner, T. Schulz and I. Seidl, "Quantifying entrepreneurship and its impact on local economic performance: A spatial assessment in rural Switzerland," Entrep Region Dev 2013. 25(3-4), 222-250.

[10] A. Cazorla and I. De los Ríos, "Rural Development as Working with People: A Proposal for Policy Management in Public Domain," UPM: Madrid, Spain, 2012, 29-35.

[11] A. Cazorla, I. de los Ríos and M. Salvo, "Working With People (WWP) in rural development projects: A proposal from social learning," Cuad Desarro Rural 2013, 10, 131-157.

[12] S. Sastre-Merino, X. Negrillo and D. Hernández-Castellano, "Sustainability of Rural Development Projects within the Working With People Model: Application to Aymara Women Communities in the Puno Region, Peru," Cuad Desarro Rural 2013, 10: 219-243.

[13] Fundación Tatiana Pérez de Guzmán el Bueno. Avalilable online : http://www.fundaciontatianapgb.org/la-fundacion/mision-y-vision/ (accessed on 15/02/2016)

[14] Análisis y prospectiva. Población y sociedad rural. (UAP Serie Agrinfo $\mathrm{n}^{\circ} 12$ ) España. Ministerio de Medio Ambiente y Medio Rural Marino, 2009.

[15] Instituto Nacional de Estadística (INE). Población, superficie y densidad por municipios por CCAA y provincias. Instituto Nacional de Estadística 2015. Available online: http://www.ine.es/(axi/tabla.do

[16] European Commission (EC) (2011). Population density. Eurostat. Available online: http://epp.eurostat.ec.europa.eu/tgm/table.do?tab=table\&init=1\&languag $\mathrm{e}=\mathrm{en} \& \mathrm{pcode}=\mathrm{tps} 00003 \&$ plugin $=1$

[17] Datos Económicos y Sociales de las Unidades Territoriales de España, 2012. Caja España-Duero, 2012.

[18] J. Urbano, Consideraciones metodológicas para la recuperación de tierras áridas degradadas. Observatorio medioambiental 2001 número 4, 49-89. 2001.

[19] ICB-NCB IPMA competence baseline, version 3.0. International Project Management Association, Nijkerk 2009.

[20] I. de los Rios-Carmenado, J. M. Díaz-Puente and J. Cadena-Iñiguez, "The Initiative Leader as a model for rural development: implementation to some territories of México," Agrociencia 2011, 45(5), 609-624.

[21] I. de Los Ríos, A. Cazorla, J. M. Díaz-Puente and J. L. Yagüe, "Projectbased learning in engineering higher education: two decades of teaching competences in real environments," Procedia Soc Behav Sci 2010, 2 (2), $1368-1378$.

[22] I. de Los Ríos, M. Ortuño and M. Rivera, "Private-Public Partnership as a Tool to Promote Entrepreneurship for Sustainable Development: WWP Torrearte Experience," Sustainability 2016, 8(3), 199

[23] I. de los Ríos, M. Rivera, C. García, "Redefining rural prosperity through social learning in the cooperative sector: 25 years of experience from organic agriculture in Spain," Land Use Policy 2016, 54, 85-94.

[24] C. A. A. Cerón, I. de los Rios-Carmenado, M. Rivera and S. Martina, (2016, March). Rural development planning in Colombia's conflict zones: A proposal from the WWP model. In International scientific conference Rural Development 2015.

[25] V. L. de Nicolás, "Towards a transformational hydraulic engineering project for the territory: A focus on the Working With People (WWP) model," Land Use Policy 2016, 54, 246-252.

[26] I. de los Ríos-Carmenado, A. T. Rahoveanu and A. A. Gallegos, "Project management competencies for regional development in Romania: analysis from "Working with People" model," Procedia Economics and Finance 2014, 8, 614-621.

[27] I. de Los Ríos, F. Rodríguez and C. Pérez, "Promoting professional Project Management skills in Engineering Higher Education: Projectbased learning (PBL) strategy," Int J Eng Educ 2015, 31 (1-B), 1-15.

[28] P. Chinnowsky, H. Brown, A. Szajnman and a. Realph, "Developing Knowledge Landscapes through Project-Based Learning," J Prof Iss Eng Ed Pr 2006, 132 (2), 118-125.

[29] J. Friedmann, "Modular cities: beyond the rural-urban divide," Environ. Urban. 1996. 8(1), 129-131. 